\title{
A new survey of the serology of human Trypanosoma cruzi infection in the Rio Negro microregion, Brazilian Amazon: a critical analysis
}

\author{
José Rodrigues Coura ${ }^{1 /+}$, Maurício Humberto Peña Marquez ${ }^{2}$, Jorge Augusto de Oliveira Guerra², \\ Patricia Lago Zauza', Julio Cesar Miguel', José Borges Pereira' \\ 'Laboratório de Doenças Parasitárias, Instituto Oswaldo Cruz-Fiocruz, Rio de Janeiro, RJ, Brasil \\ ${ }^{2}$ Instituto de Medicina Tropical do Amazonas Heitor Vieira Dourado, Manaus, AM, Brasil
}

\begin{abstract}
The serology of human Trypanosoma cruzi infection in the Rio Negro microregion is very complex because of the large numbers of false-positive cases that result from low antibody titres and cross-reactions with other infections. In the present study, we collected 4,880 blood samples on filter paper; of these, indirect immunofluorescence (IIF) was strongly reactive in 221 (4.5\%), which were considered to be positive (IIF strongly reactive; high intensity of fluorescence) and weakly reactive in 302 (6.2\%), which were considered to be doubtful (IIF weakly reactive; low intensity of fluorescence). The confirmatory test on the serum using at least two of three techniques (IIF, conventional ELISA and recombinant ELISA) on 137 samples that were positive in the screening test only confirmed 33 cases (24.1\%). Of the 178 samples that were considered doubtful in the screening test, only 10 (5.6\%) were considered to be positive in the confirmatory test. Finally, we recommend that the serological diagnosis of $\mathrm{T}$. cruzi infection in the Amazon region be made using at least two different techniques, for example immunofluorescence and ELISA and confirmed by Western blot analysis when possible.
\end{abstract}

Key words: Trypanosoma cruzi - human infection - serology - Brazilian Amazon

Previously, between 1991-1997, we conducted three serological surveys of human Trypanosoma cruzi infection in the main settlement of the municipality of Barcelos, in the Rio Negro microregion, state of Amazonas (AM) (Coura et al. 1995a, b, 1999, 2002a, b). In the first serological survey (1991), in which 710 indirect immunofluorescence (IIF) tests were performed on blood collected on filter paper, 89 (12.5\%) were positive. In the second survey conducted using the same technique in 1993, 90 of the 658 total samples $(13.7 \%)$ were also positive. Finally, in the third survey in 1997, of the 886 serum samples analysed using the Diamed ID-PaGIA agglutination test, 117 (13.2\%) were reactive. Therefore, of the 2,254 tests performed, the average positivity rate was $13.1 \%$, which seemed to be high based on epidemiological conditions of the region (Table I).

When we showed a collection of triatomines of the genera Triatoma, Panstrogylus and Rhodnius to a group of patients who we interviewed, 206 (20.7\%) recognised the insects as "piassava lice", as these triatomines are known in their region. Among the patients who recognised the triatomines, $139(67.5 \%)$ were harvesters of piassava fibre in the rural zone of Barcelos, their workplace and $62(30 \%)$ said that they had already been bitten by this insect in their huts in the piassava plantations.

doi: $10.1590 / 0074-0276130303$

Financial support: CNPq (471716/2009-0)

+ Corresponding author: coura@ioc.fiocruz.br

Received 5 June 2013

Accepted 16 August 2013
Among the individuals who reported previous attacks by triatomines, $25.8 \%$ presented antibodies for $T$. cruzi infection, while $11.7 \%$ of the individuals who had never been bitten also revealed positive serological results $(\mathrm{p}=$ 0.03) (Fig. 1). When we used the IIF test on serum with conventional and recombinant ELISA and Western blot (TESA-blot) as confirmatory tests, we were only able to confirm $2.8-5 \%$ of the tests as positive.

As a result of this previous study and due to our greater experience with Chagas disease in the area (Coura et al. 2002b, Albajar et al. 2003, Junqueira et al. 2005, Xavier et al. 2006, Brum-Soares et al. 2010), we decided in 2010 to conduct a new and larger serological survey in this area to correct certain technical interpretations regarding the previous serological surveys, including those related to immunofluorescence. For unknown reasons, intense immunofluorescence is frequently observed on the parasite's body in this region or at some points of its membrane, sometimes interpreted erroneously as positive when this staining is actually a false-positive. This staining led to the high prevalence of positivity (13.1\%) in the first screening surveys. In contrast, Diamed ID-PaGIA was shown to have low specificity in the study area.

\section{SUBJECTS, MATERIALS AND METHODS}

Location of the study area - The administrative district of Barcelos is located north of AM. To the east, it borders the state of Roraima; to the southeast and south, it borders the district of Santa Isabel do Rio Negro and, to the north, it borders Venezuela (latitude $0^{\circ} 58^{\prime} 1$ " south of the equator and longitude $62^{\circ} 56^{\prime \prime}$ west of Greenwich). The city of Barcelos, where this study was conducted, is located on the right bank of the Negro River, $490 \mathrm{~km}$ from Manaus, the capital of AM (Fig. 2). 


\section{TABLE I}

Seroprevalence for Trypanosoma cruzi infection in Barcelos, state of Amazonas, Brazil, by indirect immunofluorescence (IIF) from filter paper and serum for Diamed ID-PaGIA agglutination test

\begin{tabular}{lccc}
\hline \multicolumn{4}{c}{$\begin{array}{c}\text { Seroprevalence } \\
\left(\text { screening tests }{ }^{a}\right)\end{array}$} \\
\hline \multicolumn{3}{c}{$\begin{array}{c}\text { Tested/positive } \\
\text { n (\%) } \\
\text { Age group } \\
\text { (years) }\end{array}$} & \multicolumn{3}{c}{$1991(\mathrm{IIF})$} & $193(\mathrm{IIF})$ & $1997(\mathrm{ID}-\mathrm{PaGIA})$ \\
\hline $0-10$ & $197(7.6)$ & $248(5.6)$ & $215(12.1)$ \\
$11-20$ & $208(11.7)$ & $143(13.3)$ & $255(25.4)$ \\
$21-30$ & $91(14.3)$ & $91(9.9)$ & $139(15.7)$ \\
$31-40$ & $76(19.7)$ & $58(8.6)$ & $100(11.3)$ \\
$41-50$ & $58(12.1)$ & $42(7.1)$ & $69(7.8)$ \\
$51-60$ & $34(8.8)$ & $34(11.8)$ & $43(4.9)$ \\
$>60$ & $46(22.2)$ & $42(24)$ & $65(7.4)$ \\
\hline Total & $710(12.5)$ & $658(13.7)$ & $886(13.2)$ \\
\hline
\end{tabular}

$a$ : only $2.8-5 \%$ confirmed by IIF, ELISA and/or recombinant ELISA and Western blot. Source: Coura et al. (1999).

Survey and samples - The new serological survey was conducted in the main settlement of Barcelos and covered the entire resident population that was willing to participate in the survey after providing informed consent. For minors, the informed consent was provided by their parents or guardians. The main settlement of the municipality was divided into six areas (A-F), which were to be covered by the municipality's health agents under supervision by two laboratory technicians at the municipal hospital. The teams were trained by the project coordinator (JR Coura, a physician and infectologist) and were monitored throughout the survey by a postgraduate student (MHP Marquez). Each team was composed of two health agents; the two laboratory technicians each supervised three of the teams and all six teams were monitored by the postgraduate student.

In total, 4,880 blood samples were collected on filter paper in accordance with the technique of Souza and Camargo (1966) for the screening test: 770 samples were collected by team A (São Sebastião), 925 by team B (São Lázaro), 1,000 by team C (São Francisco), 728 by team D (Nazaré), 817 by team E (Vila Linhares) and 640 by team F (Aparecida). All the blood samples on the filter paper were eluted in $250 \mu \mathrm{L}$ of phosphate-buffered saline $(\mathrm{pH}$ 7.2) and were tested using the IIF test, as recommended by Fife and Muschel (1959) and Souza and Camargo (1966), as adapted by Ostermayer et al. (2011) for the detection of anti-T. cruzi antibodies. The IIF-Chagas kit produced by Biomanguinhos was used. In this kit, the antigens used are cultured epimastigote forms of $T$. cruzi in liver infusion tryptose medium. The tests were performed in the serology sector of the Parasitic Diseas-

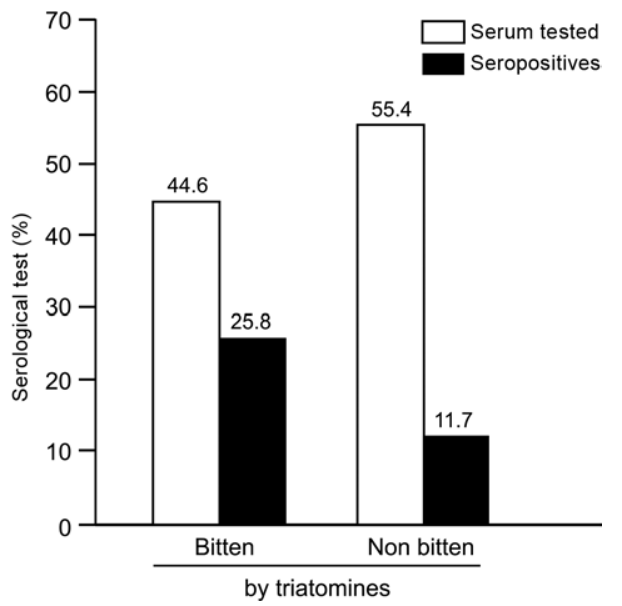

Fig. 1: percentage of seropositives in persons bitten and non bitten by triatomines in Barcelos, state of Amazonas, Brazil, 1997.

es Laboratory of the Oswaldo Cruz Institute, Oswaldo Cruz Foundation, state of Rio de Janeiro (RJ), Brazil. The slides were prepared in accordance with the classical techniques for IIF and were examined under an immunofluorescence microscope by at least two observers. The slide readings were considered to be negative (unreactive, absence of fluorescence), doubtful (weakly reactive, low intensity of fluorescence) or positive (strongly reactive, high intensity of fluorescence).

Confirmatory serological test - To perform confirmatory reactions, venous blood $(5 \mathrm{~mL})$ was collected by the laboratory technicians from 315 patients $(60 \%)$ who presented positive (137 patients; $62 \%$ ) or doubtful (178 patients; $59 \%$ ) IIF reactions to T. cruzi infection based on the serological screening of blood on the filter paper. After separation, the serum was frozen, packed on dry ice and sent from Barcelos to our laboratory in RJ. These serum samples were subjected to three serological reactions: IIF (Chagas kit, Biomanguinhos) with a dilution of 1:40, with the positive samples tittered as much as 1:1,280, conventional ELISA (DMED kit) and recombinant ELISA (Wiener Lab. V.3.0 kit). Samples were considered to be seronegative if two or three of the tests were negative and seropositive if two or three of the tests were positive. Samples that presented only one positive test were considered to be divergent.

\section{RESULTS}

Serological screening test - The screening test performed on the blood placed on the filter paper using immunofluorescence, 221 (4.5\%) of the 4,880 samples were considered to be positive (strongly reactive) and 302 (6.2\%) were considered to be doubtful (weakly positive) (Table II). Of the 4,880 samples examined, 2,741 (56.2\%) were from females and 2,139 (43.8\%) were from males. Among the 221 samples that were considered to be positive, $104(3.8 \%)$ were from females and $117(5.5 \%)$ were from males. The numbers of blood samples collected on filter paper, along with the percentage of positivity 


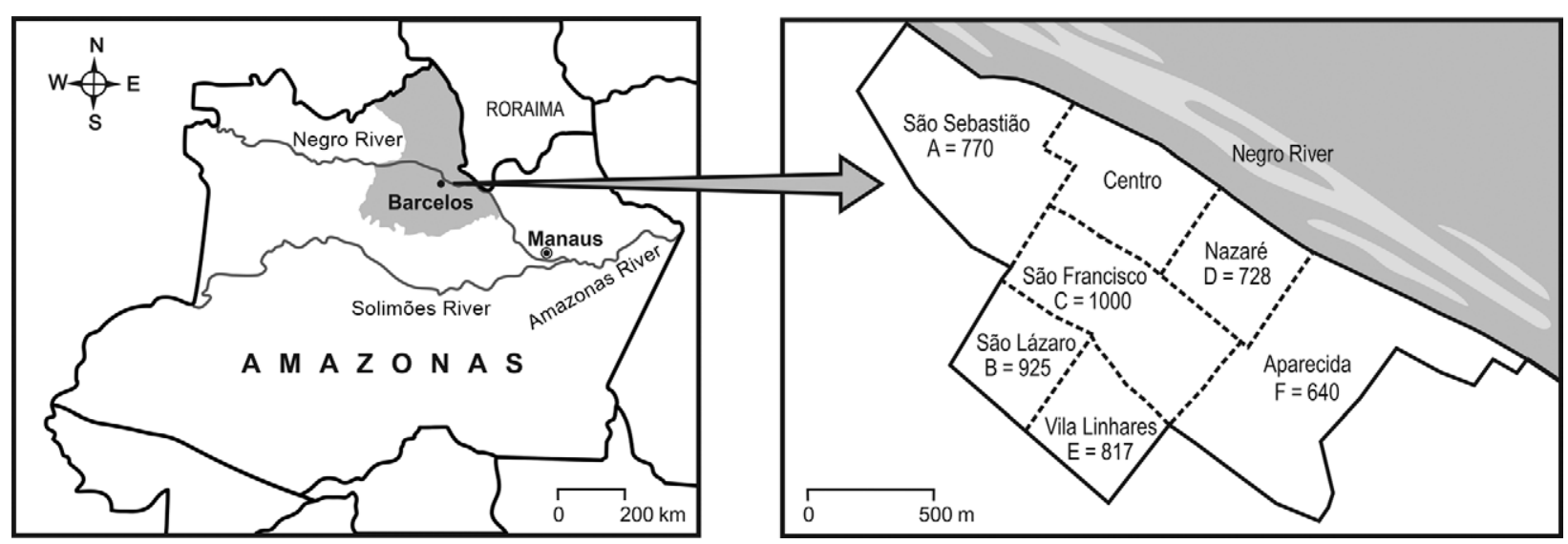

Fig. 2: location of Barcelos, state of Amazonas, Brazil, 2010, and number of blood samples collected by teams (A-F) and city district for screen tests.

TABLE II

Screening tests for Trypanosoma cruzi infection by indirect immunofluorescence (IIF) in 4,880 blood samples from filter paper

\begin{tabular}{lccc}
\hline $\begin{array}{l}\text { Age groups } \\
\text { (years) }\end{array}$ & $\begin{array}{c}\text { Tested } \\
\mathrm{n}\end{array}$ & $\begin{array}{c}\text { Positives } \\
\mathrm{n}(\%)\end{array}$ & $\begin{array}{c}\text { Doubtful } \\
\mathrm{n}(\%)\end{array}$ \\
\hline$<5$ & 495 & $9(1.8)$ & $17(3.4)$ \\
$5-9$ & 626 & $18(1.9)$ & $30(4.8)$ \\
$10-14$ & 622 & $12(2.9)$ & $30(4.8)$ \\
$15-19$ & 524 & $24(4.6)$ & $35(6.7)$ \\
$20-29$ & 872 & $46(5.3)$ & $56(6.4)$ \\
$30-39$ & 578 & $34(5.9)$ & $41(7.1)$ \\
$40-49$ & 413 & $24(5.8)$ & $39(9.4)$ \\
$50-59$ & 293 & $19(6.5)$ & $18(6.1)$ \\
$60-69$ & 227 & $17(7.5)$ & $17(7.5)$ \\
$70-79$ & 138 & $9(6.5)$ & $10(7.2)$ \\
$>79$ & 55 & $4(7.3)$ & $2(3.6)$ \\
Unknown $^{a}$ & 37 & $5(13.5)$ & $7(18.9)$ \\
\hline & 4,880 & $221(4.5)$ & $302(6.2)$ \\
\hline
\end{tabular}

$a$ : Yanomami Indians.

for $T$. cruzi infection, varied according to the number of people living in the area and their degree of exposure to infection in rural areas, especially in relation to piassava harvesters and their families. This characteristic has already been presented in previous studies by our group (Coura et al. 1995a, b, 2002a, b, 1999, Albajar et al. 2003a, b, Junqueira et al. 2005, Xavier et al. 2006, Brum-Soares et al. 2010, Coura \& Junqueira 2012, Junqueira et al. 2013).

The prevalence of serological positivity in samples collected on filter paper gradually increased after the age of 15 years, precisely when adolescents (especially males) started to be involved in piassava harvesting and after the age of 20 years among women, when as

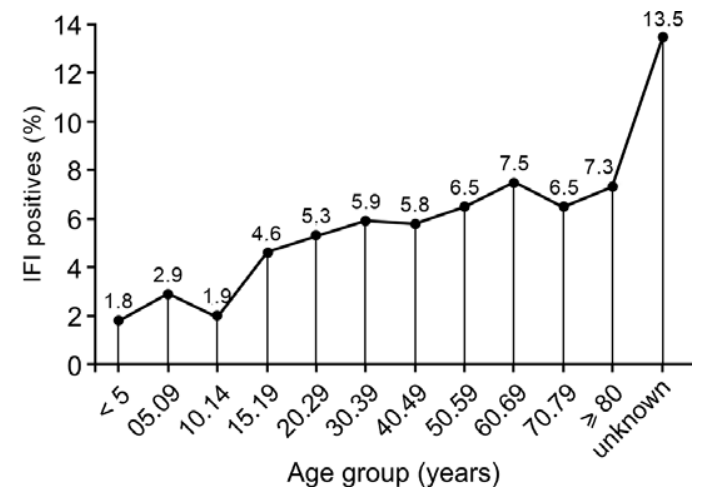

Fig. 3: percentage of positive immunefluorescence by age group in the screen tests in Barcelos, state of Amazonas, Brazil, 2010.

wives would accompany their husbands to the piassava plantations (Fig. 3, Table II). The unknown age group (Yanomami Indians who do not know their age) is the most exposed to wild triatomines in the forest; therefore, they had the highest percentage of IIF-positive results (13.5\%), as shown in Fig. 3.

Confirmatory serological test - Among the 137 serum samples that were considered to be positive based on immunofluorescence testing, 37 (27\%) were considered to be seronegative based on the confirmatory serological test, 67 (48.9\%) were considered to be serodivergent, as only one of the three reactions was positive, and only $33(24.1 \%)$ were confirmed as seropositive, with two or three positive reactions (Table III). Of the 178 serum samples for which the immunofluorescence was considered doubtful, $89(50 \%)$ were seronegative in all three confirmatory reactions, $79(44.4 \%)$ were considered to be serodivergent, with only one positive reaction out of the three reactions, and only $10(5.6 \%)$ were considered to be seropositive, with two or three positive reactions (Table III). In summary, of the 137 samples that were positive in the screening serological tests, only 33 
TABLE III

Confirmatory serological tests of 137 samples positives and 178 doubtful by indirect immunofluorescence (IIF) in blood from filter paper evaluated by IIF and ELISA conventional and or recombinant

\begin{tabular}{lcc}
\hline & \multicolumn{2}{c}{ Serological evaluation } \\
\cline { 2 - 3 } & $\begin{array}{c}\text { Positives IIF } \\
\text { from filter paper } \\
\text { n (\%) }\end{array}$ & $\begin{array}{c}\text { Doubtful IIF } \\
\text { from filter paper } \\
\text { n (\%) }\end{array}$ \\
\hline Seronegatives & $37(27)$ & $89(50)$ \\
Serodivergents & $67(48.9)$ & $79(44.4)$ \\
Seropositives & $33(24.1)$ & $10(5.6)$ \\
\hline Total & $137(100)$ & $178(100)$ \\
\hline
\end{tabular}

(24.1\%) were positive in the confirmatory tests, while only $10(5.6 \%)$ of the 178 samples that were doubtful in the screening test were positive in the confirmatory test, as shown in Table III. The numbers of serum samples and the titres of $\mathrm{IgG}$ confirmed by immunofluorescence as positive are shown in Fig. 4. These data most likely reflect the low level of parasitaemia and the particular T. cruzi strain circulating in the area (TcI), which likely provide low stimulation for antibody genesis.

\section{DISCUSSION}

The high prevalence found in the preliminary serological screening surveys that we conducted in 1991, 1993 and 1997 (Coura et al. 1999) certainly occurred due to cross-reactions with a variety of diseases that are endemic in this area, including malaria, American cutaneous leishmaniasis, tuberculosis, leprosy and Trypanosoma rangeli infection. Additionally, the low titres of anti-T. cruzi antibodies demonstrated in the present study favoured occurrences of cross-reactions with other infections. The prevalence of T. cruzi infection in Barcelos was observed to vary according to the intensity of exposure. In a group of 244 highly exposed individuals, we found that $11 \%$ were serologically positive (IIF and TESA-blot). However, among the 46 individuals in this group who underwent xenodiagnosis and polymerase chain reaction (PCR) analysis, we only isolated T. cruzi in $19 \%$ of the individuals through xenodiagnosis and the PCR was only positive in these cases (Coura et al. 1999), thus demonstrating that the parasitaemia is low in this region. Fernandes et al. (1998a, b) demonstrated only two lineages of $T$. cruzi in the area (TcI and Z3). Although no studies have provided evidence, we can suppose that these lineages of $T$. cruzi are poorly immunogenic for antibody generation.

Finally, we recommend that the serological diagnosis of T. cruzi infection in the Amazon Region should be made using at least two different techniques, e.g., immunofluorescence and ELISA and confirmed by Western blot analysis when possible.

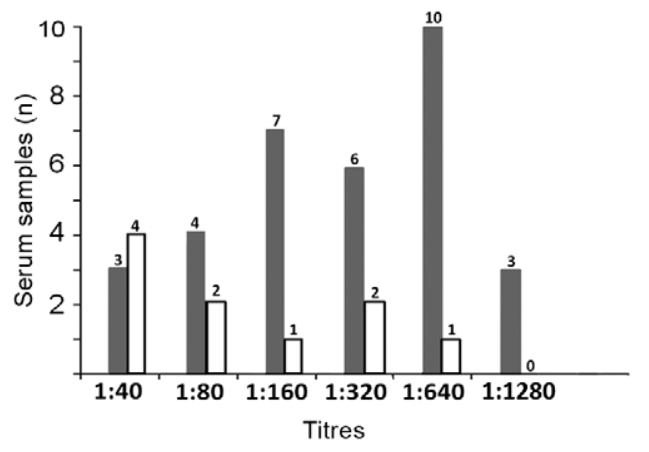

Titres of IgG immunofluorescence in serum from confirmatory serological tests out of 137 positives in the screening tests.

Titres of IgG immunofluorescence in serum from confirmatory serological tests out of 178 doubtfull in the screening tests.

Fig. 4: titres of IgG of immunofluorescence in serum from confirmatory serological tests in Barcelos, state of Amazonas, Brazil, 2011. IIF: indirect immunofluorescence.

\section{ACKNOWLEDGEMENTS}

To Eloisa Diniz, for producing the Figs 1-4.

\section{REFERENCES}

Albajar PV, Laredo SV, Terrazas MB, Coura JR 2003. Miocardiopatia dilatada em pacientes com infecção chagásica crônica. Relato de dois casos fatais autóctones do Rio Negro, estado do Amazonas. Rev Soc Bras Med Trop 36: 401-407.

Brum-Soares LM, Xavier SS, Sousa AS, Pereira JB, Ferreira JMBB, Costa IR, Junqueira ACV, Coura JR 2010. Morbidade da doença de Chagas em pacientes autóctones da microrregião do Rio Negro, estado do Amazonas. Rev Soc Med Trop 43: 170-177.

Coura JR, Arboleda Naranjo M, Willcox HPF 1995a. Chagas disease in the Brazilian Amazon. II. A serological survey. Rev Inst Med Trop São Paulo 37: 103-107.

Coura JR, Junqueira ACV 2012. Risks of endemicity, morbidity and perspectives regarding the control of Chagas disease in the Amazon Region. Mem Inst Oswaldo Cruz 107: 145-154.

Coura JR, Junqueira ACV, Boia MN, Fernandes O 1999. Chagas disease: from bush to huts and houses. Is it the case of the Brazilian Amazon? Mem Inst Oswaldo Cruz 94 (Suppl. I): 379-384.

Coura JR, Junqueira ACV, Boia MN, Fernandes O, Bonfante C, Campos JE, Santos L, Devera R 2002a. Chagas disease in the Brazilian Amazon. IV. A new cross sectional study. Rev Inst Med Trop São Paulo 44: 159-165.

Coura JR, Junqueira ACV, Fernandes O, Valente SAS, Miles MA 2002b. Emerging Chagas in Amazonian Brazil. Trends Parasitol 18: 171-176.

Coura JR, Willcox HPF, Arboleda Naranjo M, Fernandes O, Paiva DD 1995b. Chagas disease in the Brazilian Amazon. III. A crosssectional study. Rev Inst Med Trop São Paulo 37: 415-420.

Fernandes O, Souto RP, Castro JA, Pereira JB, Fernandes NC, Junqueira ACV, Naiff RD, Barret TB, Degrave W, Zingales B, Campbell DA, Coura JR 1998a. Brazilian isolates of Trypanosoma cruzi from humans and triatomines classified into two lineages using mini-exon and ribosomal RNA sequences. Am J Trop Med Hyg 58: 807-811.

Fernandes O, Sturm NR, Derre R, Campbell DA 1998b. The miniexon gene: a molecular marker for zymodeme III of Trypanosoma cruzi. Mol Biochem Parasitol 95: 129-133. 
Fife EH, Muschel LH 1959. Fluorescent antibody technique for serodiagnosis of Trypanosoma cruzi infection. Proc Soc Exp Biol Med 101: 540-543.

Junqueira ACV, Albajar PV, Coura JR 2005. Enfermedad de Chagas en la Amazonia brasileña. In Guhl F, Primer taller internacional sobre control de la enfermedad de Chagas, Universidad de los Andes, Bogotá, p. 277-287.

Junqueira ACV, Albajar PV, Coura JR 2013. Doença de Chagas na Amazônia brasileira. In JR Coura, Dinâmica das doenças infecciosas e parasitárias, 2nd ed., Guanabara Koogan, Rio de Janeiro, p. 642-648.
Ostermayer AL, Passos AD, Silveira AC, Ferreira AW, Macedo V, Prata AR 2011. O inquérito nacional de soroprevalência de avaliação do controle da doença de Chagas no Brasil (2001-2008). Rev Soc Med Trop 44: 108-121.

Sousa SL, Camargo ME 1966. The use of filter paper blood smears in a practical fluorescent test for American tripanosomiasis serodiagnosis. Rev Inst Med Trop 8: 255-258.

Xavier SS, Sousa AS, Albajar PV, Junqueira ACV, Bóia MN, Coura JR 2006. Cardiopatia chagásica crônica na Amazônia brasileira. Relato de três novos casos autóctones do Rio Negro, estado do Amazonas, comprovados por exames sorológicos, clínicos, radiográficos, eletro e ecocardiográficos. Rev Soc Bras Med Trop 39: 211-216. 